\title{
Vam Nao Deep Pools: A Critical Habitat for Pangasius krempfi and other Valuable Species in the Mekong Delta, Vietnam
}

\author{
V.A. VU, N.D. NGUYEN, E. HIDAS and M.N. NGUYEN \\ Research Institute for Aquaculture II - Department of Inland Capture Fisheries \\ 116 Nguyen Dinh Chieu St. - District 1 - Hochiminh city, Vietnam
}

\begin{abstract}
A survey of deep pools in a certain part of the Mekong Delta, southern Vietnam identified 23 deep pools based on both local knowledge and bathymetric maps. Vam Nao areas with 3 deep pools are important habitats for many Mekong species due to capture of large and important fishes such as krempfi catfish (Pangasius krempfi, Pangasiidae); giant barb (Catlocarpio siamensis, Cyprinidae); small-scale croaker (Boesemania microlepis, Sciaenidae) and soldier river barb (Cyclocheilichthys enoplos, Cyprinidae). This indicated that Vam Nao deep pools are critical habitats for Pangasius krempfi and other important fish species in the Mekong delta. Important deep pools acting as refuge habitats or spawning habitats during the dry season should be designated as fish conservation zones to protect fish stocks. Moreover, fishing co-management should be the good solution to effective management as fishing regulation enforcement is likely impossible to apply in Mekong inland fisheries. In addition, quality and quantity of existing deep pools have been affected due to increased silt deposition that resulted from dam constructions and flood mitigation schemes. Hence, water management projects should assess their possible impacts to the fisheries before implementing
\end{abstract}

\section{Introduction}

A deep pool is defined as a relatively deep area that acts as a dry season refuge and a permanent habitat for a number of important fish species within the main river channels. Mekong fishes typically migrate from the main channels to seasonal flooded areas for feeding at the beginning of the flood season, they then move out of the flooded areas into main channels at the end of the monsoon and stay in deep pools during the dry season (Swerdrup-Jensen 2002). Hydrological regimes drive fish stocks in the lower Mekong Basin (Vu 2006 and Kurien et al. 2006). Fisheries in the Mekong delta are intimately linked to hydrological factors such as water level, flood duration, flood timing, river discharge, and rainfall (Vu 2006 and Kurien et al. 2006). Monsoon is responsible

*Corresponding Author:

Email : amfpvn@hcm.fpt.vn 
for the level of seasonal flooding. Seasonal flooded areas are considered as important feeding habitats for almost all Mekong fish species during the flood season (approximately five months). Fish move back into the river as water level recedes at the onset of the monsoon season. Deeper sections of the river or deep pools are important habitats for fish during the dry season. Locations and roles of deep pools in certain sections of the Mekong River have been documented by Viravong et al. (2006); Baird (2006); Chan et al. (2005) and Poulsen et al.(2002). They show that deep pools in the Mekong River and its tributaries are crucially important dry refuge habitats for fish assemblages that provide the recruitment for the Mekong fisheries. Fish sanctuaries are likely to be related to deep pools, which are important to fish stocks and fisheries in Laos, Thailand, Cambodia, and Vietnam (Baird 2006). Ninety-five deep pools (11 - $80 \mathrm{~m}$ deep) were identified in northern Cambodia and home for approximately 168 fish species during the dry season (Chan et al. 2005). In Lao PDR, there are at least 70 deep pools identified (Poulsen et al. 2002). Seven of them as important fish habitats were found in the Khone Falls (southern Laos PDR) area, based on interviews with fishers (Roberts and Baird 1995). Some of these deep pools were established as Fish Conservation Zone by local villagers because of awareness of the important habitats during the dry season (Baird et al. 1998).

However, there is little known about the deep pools in the Mekong delta, Vietnam. The location and importance of deep pools is not extensively known. Hence, there is no policy for protecting and managing fisheries in important deep pools, which are refuge habitats for many Mekong fish species. Moreover, deep pools in the upper Mekong River play an important role in maintaining the Mekong fisheries, which are important for many people in the Lower Mekong Basin in terms of employment and food security. Consequently, there is a need to examine deep pools in the Mekong delta. Objectives of the present study are to identify existing deep pools and examine the importance of existing deep pools to the fisheries.

\section{Methods}

\section{Identification of deep pool}

The present survey was investigated to identify existing deep pools along the mainstream of a certain part of the Mekong delta, southern Vietnam. Combination of two methods was used to identify deep pools in this survey. Local knowledge method was conducted first to gather basic information about existence of deep pools. For this an informal meeting with local fishery officers and experienced fishers was organized. They were asked to locate and draw a sketch map based on their experiences. Depth 
and area of deep pools also were roughly estimated. Another approach for identifying deep pools was the use of bathymetric maps. Steps to identify deep pools were as follows: (1) define thalweg, which is a line following the lowest depths of a river; (2) plot distance against river depth; (3) subtract mean depth and (4) identify deep pools using zero-crossing method, which is based on the different depths between the deepest depth and mean depth. Current depths of identified deep pools were measured by an echo sounder JMC V-6202. In addition, based on bathymetric maps, area of each deep pool was calculated by using Microsoft AutoCAD.

\section{Importance of deep pool to the local fisheries}

One sixty seven local fishers were interviewed about their fishing activities in and around deep pools such as amount of fish catch, fishing gear, fishing habitat, fishing season, and importance of deep pools. At this stage, important deep pools to the local fisheries were recognised. In addition, local fishers usually brought their catch to the nearest markets to sell. Therefore, the daily amount of fish trading in those local markets close to those important deep pools, for one year, was monitored. Four fish vendors were chosen to monitor daily amount of fish capture trading by-species. Amount of fish trading of some important species was examined to see its distribution between seasons, particularly in the dry season, as important refuge habitats.

\section{Results}

\section{Distribution of deep pools}

Twenty-three deep pools are identified in the present survey (Fig. 1). Depth of the deepest pool is $44 \mathrm{~m}$. There are two deep pools greater than $40 \mathrm{~m}$ deep; five deep pools greater than $30 \mathrm{~m}$ deep; nine deep pools greater than $20 \mathrm{~m}$ deep and the remaining greater than $10 \mathrm{~m}$ deep. The largest pool has 95 ha and one deep pool with 4 ha is the smallest pool. There are four deep pools with 50 - 70 ha; four deep pools with 30 - 50 ha and twelve deep pools with 10 - 30ha. Dominant identified deep pools ranged from 20 - $30 \mathrm{~m}$ deep and 10 - 30 ha.

The relationship between maximum depth and area of deep pools are shown in Fig.2a. There is a difference between depth estimation based on bathymetric maps and echo-sounder measurement. If two estimates are the same, all points will place in the dashed line (Fig. 2b). However, they are many outlines around the dashed line. It indicates that morphological characteristics of existing deep pools have been changed over time. Hydrological regimes are the main factors influencing the morphological 
characteristics of deep pools; moreover, the hydrological regimes vary from year to year in the Mekong River partly because of water management projects (dam constructions; flood mitigation schemes). Therefore, several deep pools have been affected by siltation, leading to change in its dimensions.

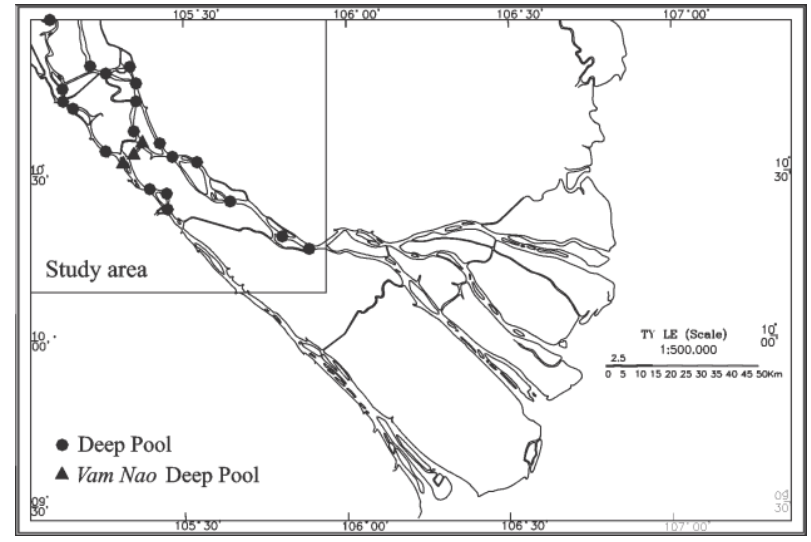

Figure 1. Distribution of identified deep pools in the Mekong delta

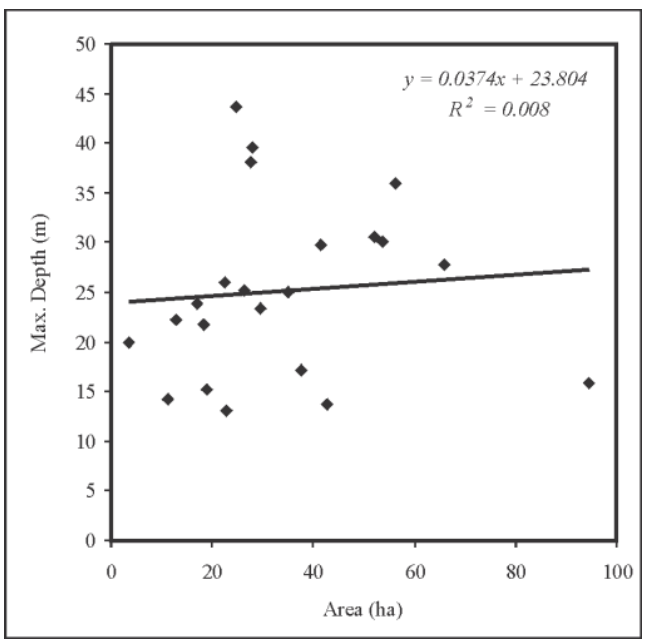

Figure 2a. Relationship between maximum depth and area of deep pools

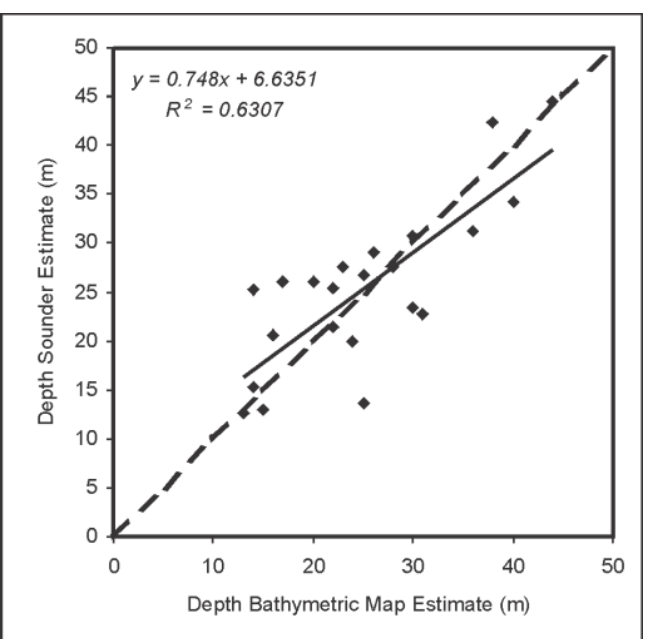

Fig. 2b. Difference between depth from bathymetric maps and echo-sounder estimate

Another reason for different depth estimations based on bathymetric maps and echo-sounder measurement is that sand in riverbed has been exploited heavily in a certain part of the river in recent years. This activity leads to changes in morphological characteristics in the riverbed and may have various impacts on the fisheries.

\section{Importance of deep pools to the local fisheries:}

Vam Nao area where there are three deep pools (Fig. 1) is claimed to be the most important fishing habitat. In addition, local fishers confirmed that amount of fish catch 
in Vam Nao area is more than that in other fishing habitats, especially, fish species caught are usually large.

In addition, there are 19 fishing gear types operating in and around 23 deep pools. Gillnet and trawl nets are the most popular gears in the Mekong delta. Among those gears, there is one type of special gillnet called krempfi gillnet used to target large fish (140 - 180mm in diamond mesh-size), particularly, krempfi catfish (Pangasius krempfi, Pangasiidae). Moreover, there is a fishing community using krempfi gillnet (50 fishers) in Vam Nao area, whereas there is only one or two krempfi gillnet fishers in several deep pools remaining.

Total monthly amount of fish trading of four large and important species in one local market close to Vam Nao area with three important deep pools were examined with respect to its distribution and importance to the local fisheries. The first of two species are particularly important in the Mekong delta: krempfi catfish (Pangasius krempfi, Pangasiidae) and giant barb (Catlocarpio siamensis, Cyprinidae). The two species mainly distribute in Vam Nao area during the dry season (Figs. 3 and 4).

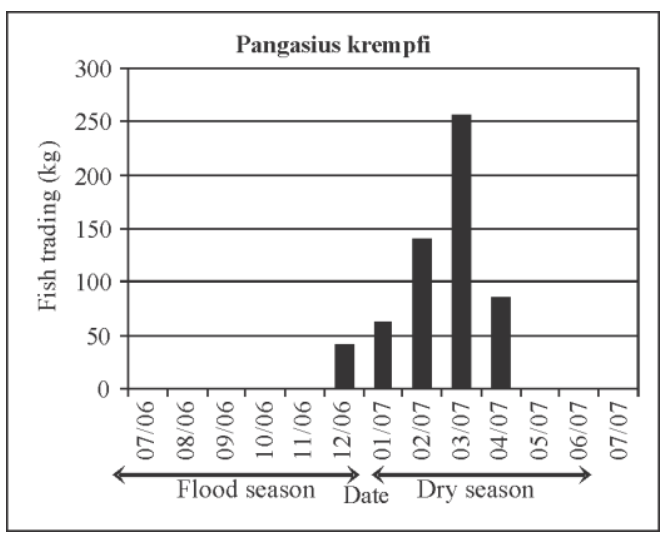

Figure 3. Total monthly amount of krempficatfish trading at a local market

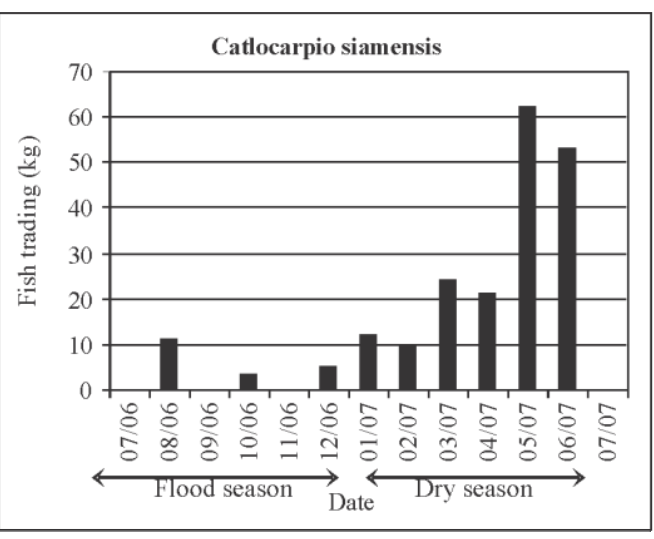

Figure 4. Total monthly amount of giant barb trading at a local market

Amount of fish trading of other two important species are shown in Fig. 5 and Fig. 6 namely, small-scale croaker (Boesemania microlepis, Sciaenidae) and soldier river barb (Cyclocheilichthys enoplos, Cyprinidae). As observed, the two species distribute all year round in Vam Nao area and there is higher fish trading during the flood season. 


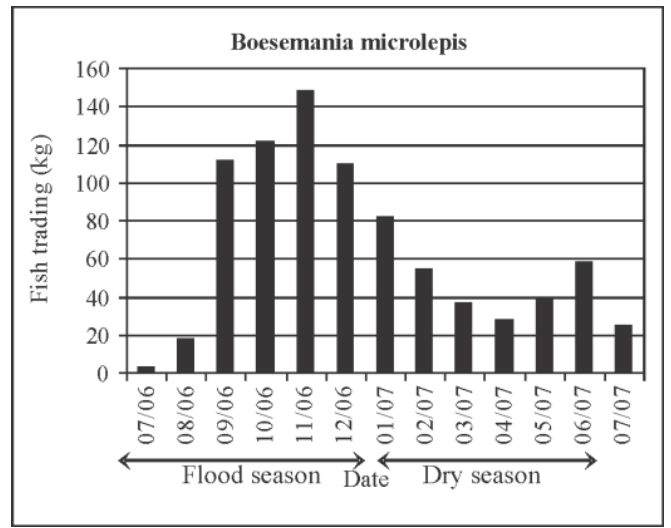

Figure 5. Total monthly amount of small-scale croaker trading at a local market

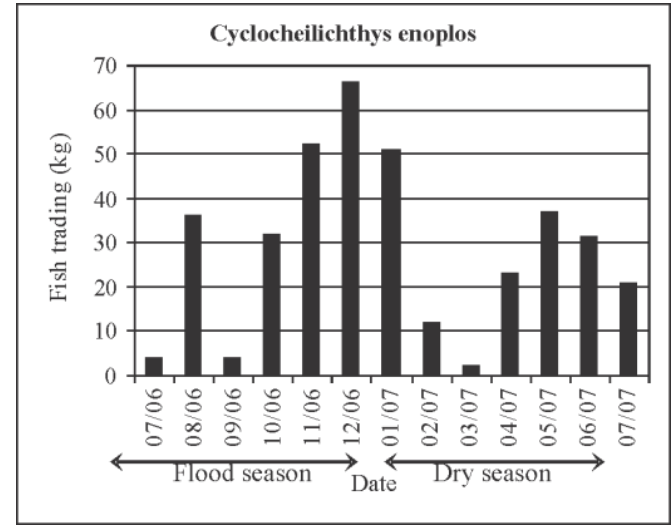

Figure 6. Total monthly amount of soldier river barb trading at a local market

\section{Discussion}

There are 23 deep pools identified in the upper part of the Mekong delta (Fig. 1). Number of deep pools in the Mekong delta is fewer than those in Cambodia (95 deep pools; Chan et al. 2005), also fewer than those in Laos (at least 70 deep pools; Poulsen et al. 2002). Deep pools areas in the Mekong delta are also smaller compared to other countries in the Lower Mekong Basin (LMB). Mekong delta is a downstream area and the final part of the LMB. Thus, difference of water level between the dry and the flood seasons in upstream is greater than that in the Mekong delta, downstream. For example, the difference in Phnom-Penh station (Cambodia) is approximately 7.5 - $9 \mathrm{~m}$, while the difference in the Mekong delta is approximately $3-4 \mathrm{~m}$. The higher the difference of water level between the dry and the flood seasons, the stronger is the water current. Stronger water current often scours much sediment in riverbed, probably resulting in deeper and more pools. Deep pools often occur at meander bends and straight alluvial channels because of secondary circulation and occur at constrictions and confluence zones in a channel because of flow convergence. There is no relationship between maximum depth and area among deep pools $\left(r^{2}=0.008 ; P=0.673\right.$; Fig. 2). In addition, Chan et al. (2005) show that there is no relationship between area and depth of deep pools in Cambodia.

Morphological characteristics of existing deep pools have been changed over time (Fig. 3). The fact is that water management projects such as dam construction and flood mitigation schemes have affected the quality and quantity of deep pools due to increased silt deposition. For example, some deep pools have become shallower resulting from the Yali Dam in the upper part of the Sesan River Basin (Fisheries Office of 
Ratanakiri Province, Cambodia, 2000). Similarly, there was a decrease of $7-8 \mathrm{~m}$ in one deep pool in Voen Say district. As a result, many catfish species disappeared in this area (Fisheries Office of Ratanakiri Province, Cambodia, 2000). Furthermore, construction of Theun-Hinboun Dam in Laos also showed the same results (Poulsen et al. 2002).

Several tentative indicators were developed to assess the important habitats within the Mekong River such as depth, current speed, substrate, slope, proximity to wetland forest, and occurrence of objects within the habitat (Baird et al. 1998). Depth and slope parameters related to morphological characteristics of deep pools are indicators to classify critical habitats. It implies that existence of deep pools play a crucial role in the Mekong River ecosystem. Deeper and larger pools are not always important habitats. For instance in the study, two pools are very deep (40 - $44 \mathrm{~m})$, however, they are not considered to be critical habitats to the fisheries.

Vam Nao deep pools (Fig. 1) are admitted to be important habitats in the Mekong delta. The authors decided to monitor amount of fish trading in one local market for one year close to Vam Nao deep pools as local fishers often sell their catch at the nearest market. Krempfi catfish is a large species, which is only available during the dry season (Fig. 3). It indicates that this is a critical habitat for krempfi catfish. The largest amount of krempfi catfish trading occurs in March $\left(255 \mathrm{~kg} \mathrm{month}^{-1}\right)$. This time coincides with time of upstream migration for spawning. Although krempfi catfish migrate from South China Sea and Mekong delta estuarine to Khone Falls to spawn in June and July (Hogan et al. 2007), there are no adults caught in spawning condition in March in Vam Nao area. In addition, krempfi catfish is an anadromous species, similar to life history of salmon and undertake the longest migration routes among Mekong species (Hogan et al. 2007). After spawning, this species migrates back to the estuary and South China Sea; however, no fish are available in the local market during the flood season (Fig. 3). It shows that most of the adults may get caught when they migrate back to the sea.

Similarly, giant barb trading is mainly during the dry season (Fig. 4). Therefore, Vam Nao is an important habitat for this species during the dry season. Giant barb is found rarely in the Mekong River, particularly large fish. On the other hand, amount of fish trading of other two large and important species (small-scale croaker and soldier river barb) has the same pattern. The two species are available in the local market all year round, especially, more fish are caught at the end of the flood season (Figs. 5 \& 6). Therefore, Vam Nao deep pools are also important habitats for those species. Water level starts receding at the end of the flood season, fish also move back to main channels and concentrate in deeper areas or deep pools within the river. Therefore, more fish are 
caught at the end of the flood season, as local fishers are aware of the migration pattern and target migratory species. Thus, more fish are available at the local market at that time.

Deep pools in upstream of the Mekong River (Cambodia and Laos) are likely to be more important habitats than those in the Mekong delta, downstream. One of the reasons being that most Mekong white fish spawn in upstream, somewhere in Kratie Stung Treng (Cambodia) and around Khone Falls (Laos). Larvae and juveniles then drift downstream to flooded areas such as Mekong delta, Vietnam (Poulsen et al. 2002). Thus, spawning does not take place in the Mekong Delta for almost all Mekong white fish species. Another reason is that water level in the northern Cambodia and Laos during the dry season is very low and may expose to riverbed at certain sections of the river. Hence, deep pools upstream are more critical habitats for fish survival during the dry season.

Quality and quantity of existing deep pools have been affected due to increased silt deposition that resulted from dam constructions and flood mitigation schemes. Hence, water management projects should assess their possible impacts to the fisheries before implementing by using environmental impact assessment procedure.

Some species are highly migratory between countries, particularly, krempfi catfish. They depend on different habitats in different countries, especially, in the dry season where water level is low. Riparian countries of the Mekong Basin should take the issue into account to manage transboundary stocks. Therefore, important deep pools acting as refuge habitats or spawning habitats during the dry season should be designated as fish conservation zones to protect fish stocks. Moreover, fishing co-management should be the good solution to effective management as fishing regulation enforcement is likely impossible to apply in Mekong inland fisheries.

\section{References}

Baird I.G. 2006. Strength in diversity: fish sanctuaries and deep-water pools in Lao PDR. Fisheries Management and Ecology, vol.13, pp 1-8.

Baird, I.G., P. Kisouvannalath, V. Inthapphaysi and B. Phylaivanh .1998. The potential for ecological classification as a tool for establishing and monitoring fish conservation zones in the Mekong River. Technical Report No.2. Environmental Protection and Community Development in the Siphandone Wetland, Champasak Province, Lao PDR.

Chan S., S. Putrea, K. Sean and H.G. Hortle 2005. Using knowledge to ventory deep pools, important fish habitats in Cambodia. In: procedings of the $6^{\text {th }}$ Technical Symposium on Mekong Fisheries $\left(6^{\text {th }}\right.$ Technical Symposium on Mekong Fisheries, Pakse, Lao PDR, 26 $6^{\text {th }}-28^{\text {th }}$ November 2003) (Eds T.J. Burnhill and M.M. Hewitt) pp. 57-76. Mekong River Commission, Vientiane. 
Fisheries Office of Ratanakiri Province. 2000. A study of the downstream impacts of the Yali Dam in the Sesan River Basin in Ratanakiri province, northeast Cambodia. Report prepared in cooperation with the Non-Timber Products Project.

Hogan, Z., I.G. Baird, R. Radtke and M.J. Vander Zanden. 2007. Long distance migration and marine habitation in the tropical Asian catfish, Pangasius krempfi. Journal of Fish Biology. 71: 818 - 832.

Kurien J., E. Baran. and S. Nam. 2006. Factors that drive Cambodia's inland fish catch: what role can community fisheries play? Inland Fisheries Research and Development Institute, Phnom Penh, Cambodia, 12 pp.

Poulsen A., P. Ouch, S. Viravong, U. Suntornratana and T.T. Nguyen. 2002. Deep pools as dry season habitat in the Mekong River Basin. Phnom Penh: Mekong River Commission MRC Technical Paper No. 4, 22 pp.

Roberts T.R. and I.G. Baird. 1995. Traditional fisheries and fish ecology on the Mekong at Khone Waterfalls in southern Laos. Natural History Bulletin of the Siam Society, 1995, 43: 219-262.

Swerdrup-Jensen S. 2002 Fisheries in the Lower Mekong Basin: Status and Perspectives. MRC Technical Paper No. 6, $103 \mathrm{pp}$.

Viravong S., S. Phounsavath, C. Photitay, S. Putrea, S. Chan , J. Kolding, J. Valbo-Jorgensen and K. Phoutavong .2006. Hydro-acoustic survey of deep pools in the Mekong River in Southern Lao PDR and Northern Cambodia. MRC Technical Paper No. 11, 67 pp.

Vu V. A. 2006. Effect of hydrology on fish catch in the Lower Mekong River, Vietnam. Master thesis, Australian Maritime College. 